\title{
Strategi Pengembangan Usaha Ternak Ayam Broiler di Kecamatan Sangatta Selatan Kabupaten Kutai Timur
}

\author{
Al Hibnu Abdillah ${ }^{1}$ dan Heny Arnila ${ }^{2}$ \\ 1,2 Program Studi Agroteknologi Sekolah Tinggi Pertanian Kutai Timur, Jl. Soekarno-Hatta, \\ Sangatta Utara Kutai Timur, 75611. \\ 1 Email: alhibnu_abdillah@stiperkutim.ac.id \\ 2 Email: heny.arnilaismail@gmail.com
}

\begin{abstract}
Broiler chicken business is a type of business that very potential to developed. This study aims to find out the strategy for developing broiler chicken livestock in Sangatta Selatan Subdistrict, which was conducted from February to May 2018 in Sangatta Selatan Subdistrict, East Kutai District. This research was conducted using the Focus Group Discussion (FGD) method with 8 respondents. This research uses descriptive analysis method and SWOT analysis. Results showed that broiler chicken livestock in Sangatta Selatan Subdistrict in quadrant I, which means that this situation is very profitable, this business has the opportunity and strength so that it can take advantage of opportunities. The development strategy in broiler chicken livestock in Sangatta Selatan Subdistrict is aggressive strategy, namely to use strenght to take advantage of existing opportunities

Keywords: broiler chicken, strategy, FGD, SWOT analysis
\end{abstract}

\begin{abstract}
ABSTRAK
Usaha ayam broiler merupakan jenis usaha yang sangat potensial dikembangkan. Penelitian ini bertujuan untuk mengetahui strategi pengembangan usaha ternak ayam broiler di Kecamatan Sangatta Selatan yang dilakukan pada bulan Februari sampai Mei 2018 di Kecamatan Sangatta Selatan, Kabupaten Kutai Timur. Penelitian ini dilakukan dengan metode Focus Group Discussion (FGD) dengan responden sebanyak 8 orang. Penelitian ini menggunakan metode analisis deskriptif dan analisis SWOT. Hasil penelitian menunjukkan bahwa usaha ternak ayam broiler di Kecamatan Sangatta Selatan berada pada kuadran I, yang berarti bahwa situasi ini sangat menguntungkan, usaha ini memiliki peluang dan kekuatan sehingga dapat memanfaatkan peluang yang ada. Strategi pengembangan pada usaha ternak ayam broiler di Kecamatan Sangatta Selatan adalah strategi agresif, yaitu menggunakan kekuatan untuk memanfaatkan peluang yang ada
\end{abstract}

Kata kunci: ayam broiler, strategi, FGD, analisis SWOT

\section{Pendahuluan}

Sektor pertanian memiliki peranan penting diantara sektor lainnya dalam perekonomian nasional. Hal ini tercermin dari tingkat produksi, penyerapan tenaga kerja, serta sumbangsih pendapatan yang bekerja di sektor tersebut. Pada prinsipnya, pembangunan pertanian bertujuan untuk meningkatkan produksi menuju arah swasembada, memperluas kesempatan kerja dan meningkatkan taraf hidup rakyat. Untuk mencapai tujuan tersebut, salah satu sub sektor pertanian yakni sub sektor peternakan harus dilakukan pengembangan secara luas (Kurniati, 2014). Salah satu bagian dari sektor pertanian adalah subsektor peternakan.

Ayam broiler merupakan salah satu jenis unggas yang memberikan sumbangsih besar dalam memenuhi kebutuhan protein asal hewani bagi masyarakat Kabupaten Kutai Timur. Menurut Umam, dkk, (2015), ayam jenis ini adalah memiliki kemampuan laju pertumbuhan yang sangat cepat, karena dapat dipanen pada umur 5 minggu. Keunggulan 
tersebut didukung oleh sifat genetik dan keadaan lingkungan yang meliputi makanan, temperatur lingkungan, dan pemeliharaan. Ayam broiler memiliki prospek pasar yang luas. Menurut Ensmingeret, dkk., (2004) dalam Ulupi, dkk, (2015), ayam broiler juga memiliki kelebihan dalam hal tidak memerlukan tempat luas dalam pemeliharaan, memiliki pertumbuhan cepat dan efisien dalam mengubah pakan menjadi daging. Ayam broiler memiliki kelemahan yakni cenderung rentan terhadap serangan penyakit.

Kabupaten Kutai Timur merupakan satu diantara sepuluh kabupaten/kota yang berada di wilayah Provinsi Kalimantan Timur. Kabupaten ini memiliki potensi besar, salah satunya di sektor pertanian. Menurut Badan Pusat Statistik Kab. Kutai Timur (2017), Kabupaten Kutai Timur merupakan kabupaten hasil pemekaran dari Kabupaten Kutai, memiliki luas wilayah sebesar $35.747,50 \mathrm{~km}^{2}$ atau $17 \%$ dari total luas Provinsi Kalimantan Timur. Memiliki 18 kecamatan, salah satunya adalah Kecamatan Sangatta Selatan.

Perunggasan di Kabupaten Kutai Timur, populasi ayam broiler terbanyak yaitu di Kecamatan Sangatta Selatan. Berdasarkan Badan Pusat Statistik Kabupaten Kutai Timur (2018), populasi ayam broiler pada tahun 2013 sebanyak 866.888 ekor; tahun 2015 sebanyak 971.797 ekor; dan tahun 2016 sebanyak 802.174 ekor. Pada tahun 2015 jumlah produksi daging ayam broiler di Kecamatan Sangatta Selatan sebesar $381.800 \mathrm{~kg}$ dan jumlah konsumsi daging ayam broiler di Kecamatan Sangatta Selatan yaitu sebanyak $362.710 \mathrm{~kg}$. Usaha ayam broiler sangat potensial untuk dikembangkan. Beberapa faktor yang mendukung usaha ayam broiler sebenarnya masih dapat terus dikembangkan, antara lain jumlah permintaan dan banyaknya populasi ayam broiler di Kecamatan Sangatta Selatan. Kondisi demikian perlu untuk dilakukan pembenahan manajemen dan strategi agar usaha ternak ayam broiler bisa berkembang lebih baik lagi. Penelitian ini bertujuan untuk mengetahui strategi pengembangan usaha ternak ayam broiler di Kecamatan Sangatta Selatan Kabupaten Kutai Timur.

\section{Metodologi Penelitian}

Penelitian ini dilakukan pada bulan Februari hingga Mei 2018 di Kecamatan Sangatta Selatan, Kabupaten Kutai Timur. Metode pengumpulan data yang digunakan dalam penelitian ini terdiri dari data primer dan data sekunder. Pengumpulan data primer digunakan dengan metode Focus Group Discussion (FGD). Metode ini terbukti dapat memberikan data yang lebih mendalam, lebih informatif dan lebih bernilai dibanding metode lainnya (Afiyanti, 2008). Metode FGD adalah salah satu teknik pengumpulan data kualitatif yang didesain untuk memperoleh informasi keinginan, kebutuhan, sudut pandang, kepercayaan, dan pengalaman peserta tentang suatu topik dengan pengarahan dari seorang fasilisator atau moderator (Paramita dan Kristiana, 2013). Pengambilan sampel pada penelitian ini dilakukan berdasarkan metode sampling jenuh, yaitu 
mengambil semua populasi menjadi sampel dengan jumlah 4 peternak ayam broiler. Hal ini dilakukan apabila jumlah populasi kurang dari 30 orang (Sugiyono, 2014). Penentuan peserta FGD dilakukan dengan metode purposive sampling, dengan jumlah 8 responden yang terdiri dari 4 peternak ayam broiler, 1 staf Kecamatan Sangatta Selatan, 1 akademisi, 1 tokoh masyarakat dan 1 masyarakat sekitar.

Metode analisis yang digunakan pada penelitian ini yaitu dengan menggunakan analisis deskriptif kualitatif dan analisis SWOT. Analisis SWOT dilakukan dengan membandingkan antara faktor internal (kekuatan dan kelemahan) dengan faktor eksternal (peluang dan ancaman). Faktor internal dimasukan ke dalam matriks yang disebut Internal Factor Analysis Summary (IFAS), sedangkan faktor eksternal dimasukkan ke dalam matriks yang disebut dengan External Factor Analysis Summary (EFAS).

Internal Factor Analysis Summary (IFAS) dan External Factor Analysis Summary (EFAS)

Menurut Rangkuti (2008), sebelum dilakukan analisis SWOT, dilakukan klasifikasi dan analisis faktor internal (kekuatan dan kelemahan). Prosedur IFAS sebagai berikut:

i. Menentukan faktor-faktor yang menjadi kekuatan serta kelemahan perusahaan dalam kolom 1.

ii. Memberi bobot masing-masing faktor tersebut dengan skala mulai 1,0 (paling penting) sampai 0,0 (tidak penting).

iii. Menghitung rating (dalam kolom 3) untuk masing-masing faktor dengan memberikan skala mulai dari 4 (nilai tertinggi) sampai dengan 1 (nilai terendah).

iv. Mengalikan bobot pada kolom 2 dengan rating pada kolom 3, untuk memperoleh faktor pembobotan dalam kolom 4. Hasilnya berupa skor pembobotan untuk masing-masing faktor yang nilainya bervariasi mulai dari 4,0 sampai dengan 1,0.

v. Menjumlahkan skor pembobotan (pada kolom 4) untuk memperoleh total skor pembobotan bagi usaha.

Bentuk matriks IFAS dan EFAS dapat dilihat pada Tabel 1 dan Tabel 2.

Tabel 1. Matriks Internal Factor Analysis Summary (IFAS)

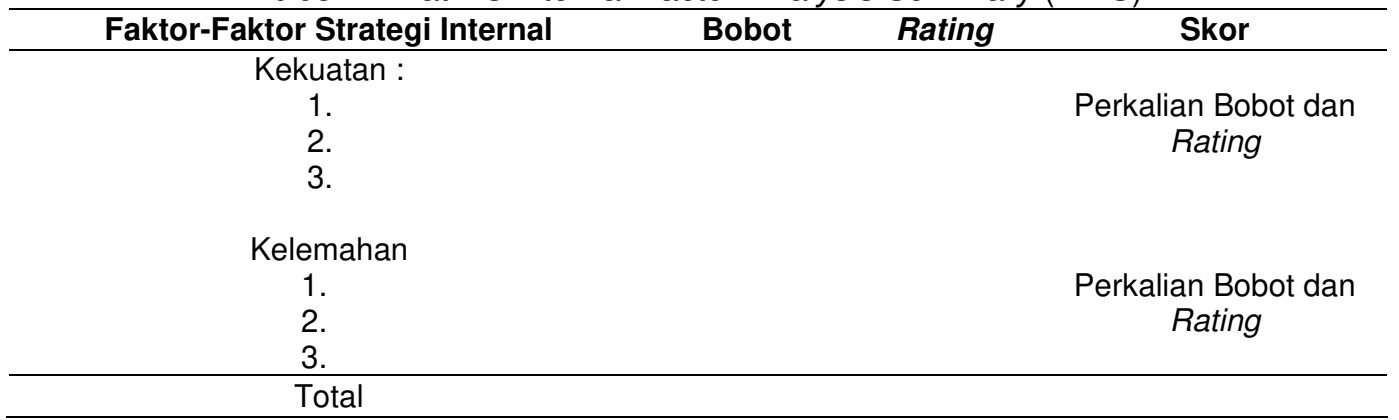

Menurut Rangkuti (2008), prosedur analisis faktor eksternal adalah sebagai berikut:

i. Menyusun peluang dan ancaman dalam kolom 1 
ii. Memberi bobot masing-masing faktor dalam kolom 2, mulai dari 1,0 (sangat penting) sampai dengan 0,0 (tidak penting)

iii. Menghitung rating (dalam kolom 3) untuk masing-masing faktor dengan memberikan skala mulai dari 4 (nilai tertinggi) sampai dengan 1 (nilai terendah)

iv. Mengalikan bobot pada kolom 2 dengan rating pada kolom 3, untuk memperoleh faktor pembobotan dalam kolom 4. Hasilnya berupa skor pembobotan untuk masing-masing faktor yang nilainya bervariasi mulai dari 4,0 sampai dengan 1,0

v. Menjumlahkan pembobotan (pada kolom 4) untuk memperoleh total skor pembobotan bagi usaha

Tabel 2. Matriks External Factor Analysis Summary (EFAS)

\begin{tabular}{ccc}
\hline Faktor-Faktor Strategi Eksternal & Bobot & Rating \\
\hline Kekuatan : & & Skor \\
1. & Perkalian Bobot dan \\
2. & Rating \\
3. & \\
Kelemahan & Perkalian Bobot dan \\
1. & Rating \\
2. & \\
3. & \\
\hline Total & \\
\hline
\end{tabular}

\section{Matriks Internal-Eksternal}

Setelah menentukan matrik IFAS dan EFAS, disusun Matriks Internal-Eksternal untuk melihat strategi yang tepat untuk diterapkan.

Total Skor Faktor Strategi Internal

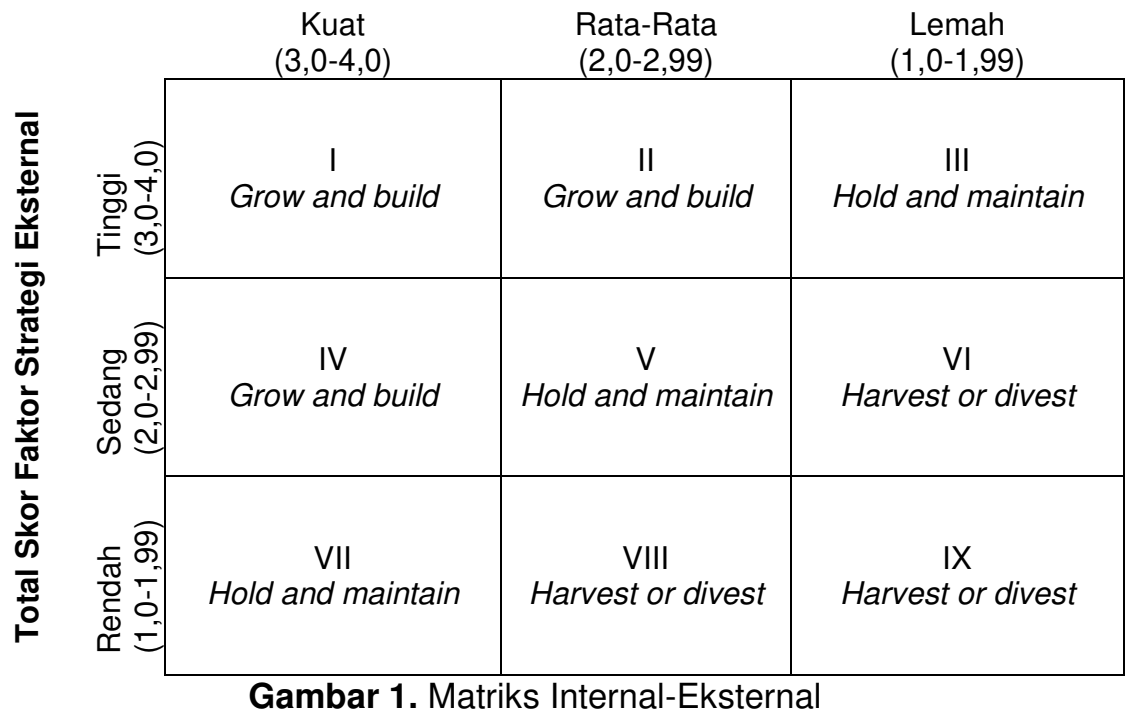

Sel I, II, dan IV digambarkan sebagai tumbuh dan membangun. Sel III, V atau VII digambarkan sebagai menjaga dan mempertahankan.

\section{Matriks dan Diagram SWOT}

Matriks SWOT merupakan alat yang dipakai untuk menyusun faktor-faktor strategis perusahaan (Rangkuti, 2008). Matriks ini dapat mengambarkan secara jelas 
bagaimana peluang dan ancaman eksternal yang dihadapi perusahaan dapat disesuaikan dengan kekuatan dan kelemahan yang dimilikinya. Matriks ini dapat menghasilkan empat set kemungkinan alternatif strategis, yang dapat dilihat pada Tabel 3.

Tabel 3. Matriks SWOT

\begin{tabular}{ccc}
\hline IFAS & $\begin{array}{c}\text { STRENGTHS }(\mathrm{S}) \\
\text { Tentukan faktor-faktor } \\
\text { kekuatan internal }\end{array}$ & $\begin{array}{c}\text { WEAKNESS (W) } \\
\text { Tentukan kelemahan internal }\end{array}$ \\
\hline $\begin{array}{c}\text { OPPORTUNITIES }(\mathrm{O}) \\
\text { Tentukan faktor peluang } \\
\text { eksternal }\end{array}$ & $\begin{array}{c}\text { STRATEGI SO } \\
\text { Ciptakan strategi yang } \\
\text { meggunakan kekuatan untuk } \\
\text { memanfaatkan peluang }\end{array}$ & $\begin{array}{c}\text { STRATEGI WO } \\
\text { Ciptakan strategi yang } \\
\text { meminimalkan kelemahan } \\
\text { untuk memanfaatkan peluang }\end{array}$ \\
\hline $\begin{array}{c}\text { Tentukan faktor ancaman }(\mathrm{T}) \\
\text { eksternal }\end{array}$ & $\begin{array}{c}\text { STRATEGI ST } \\
\text { Ciptakan strategi yang } \\
\text { menggunakan kekuatan untuk } \\
\text { mengatasi ancaman }\end{array}$ & $\begin{array}{c}\text { STRATEGI WT } \\
\text { Ciptakan strategi yang } \\
\text { meminimakan kelemahan dan } \\
\text { menghindari ancaman }\end{array}$ \\
\hline
\end{tabular}

Menurut Rangkuti (2008), keputusan memilih alternatif strategi dilakukan setelah perusahaan mengetahui posisi perusahaan dalam kuadran, sehingga strategi yang dipilih merupakan strategi yang paling tepat karena sesuai dengan kondisi internal dan eksternal. Posisi perusahaan dapat dikelompokkan dalam empat kuadran.

i. Jika posisi perusahaan berada pada kuadran I, maka menandakan bahwa situasi ini sangat menguntungkan, perusahaan tersebut memiliki peluang dan kekuatan sehingga dapat memanfaatkan peluang yang ada. Strategi yang harus diterapkan untuk perusahaan yang berada pada posisi ini adalah mendukung pertumbuhan yang agresif

ii. Perusahaan yang berada pada kuadran II berarti perusahaan menghadapi berbagai ancaman, namun perusahaan masih memiliki kekuatan internal. Strategi yang harus dilakukan adalah menggunakan kekuatan untuk memanfaatkan peluang jangka panjang dengan cara strategi diversifikasi (produk/jasa).

iii. Perusahaan yang berada pada kuadran III menunjukkan bahwa perusahaan mempunyai peluang yang sangat besar, tetapi di lain pihak perusahaan memiliki kelemahan internal.

iv. Posisi perusahaan pada kuadran IV menunjukkan bahwa perusahaan menghadapi situasi yang sangat tidak menguntungkan, dimana selain perusahaan menghadapi berbagai ancaman juga menghadapi kelemahan internal.

\section{Hasil dan Pembahasan}

Kecamatan Sangatta Selatan terletak pada 0¹8'39" s/d 0²9'44" Lintang Utara dan 117 $28^{\prime} 44^{\prime \prime}$ s/d 117 $36^{\prime} 43^{\prime \prime}$ Bujur Timur. Kecamatan Sangatta Selatan menempati 
daerah seluas kurang lebih $14.716 \mathrm{Ha}$. Kecamatan Sangatta Selatan memiliki 4 desa, antara lain Desa Sangatta Selatan dengan jumlah 4 dusun dan 18 Rukun Tetangga, Desa Singa Geweh dengan 4 Dusun dan 18 Rukun Tetangga, Desa Sangkima sebanyak 5 Dusun dan 18 Rukun Tetangga dan Desa Teluk Singkama sebanyak 2 dusun dan 9 Rukun Tetangga. Penduduk di Kecamatan Sangatta Selatan pada tahun 2016 berjumlah 23.768 jiwa. Penduduk laki-laki berjumlah 12.760 orang dan penduduk perempuan berjumlah 11.008 orang. Untuk menunjang perekonomian di Kecamatan Sangatta Selatan terdapat 3 pasar, 4 koperasi, 248 toko/warung, 2 rumah makan dan 31 kedai makanan/minuman.

\section{Analisis Lingkungan Internal}

Menilai suatu usaha perlu dilakukan terlebih dahulu mengenai identifikasi lingkungan internal maupun lingkungan eksternal. Faktor-faktor dari analisis lingkungan internal pada usaha ternak ayam broiler di Kecamatan Sangatta Selatan dapat dilihat pada Tabel 4.

Tabel 4. Analisis Lingkungan Internal Usaha Ternak Ayam Broiler di Kecamatan Sangatta Selatan

Faktor-Faktor Internal

\begin{tabular}{|c|c|}
\hline Kekuatan (Strenghts): & Kelemahan (Weakness): \\
\hline 1. Tersedianya lahan & 1. Teknologi masih sederhana \\
\hline 2. Tersedianya bahan baku & 2. Terbatasnya modal yang berasal dari \\
\hline 3. Tersedianya peralatan & modal pribadi peternak \\
\hline $\begin{array}{l}\text { 4. Tersedianya pinjaman modal dari } \\
\text { perusahaan mitra }\end{array}$ & $\begin{array}{l}\text { 3. Kurangnya pengalaman mengenai } \\
\text { budidaya ayam broiler }\end{array}$ \\
\hline 5. Pemasaran hasil panen yang terjamin & 4. Pengobatan kurang maksimal \\
\hline
\end{tabular}

Lingkungan internal menggambarkan beberapa kekuatan dan juga kelemahan yang berpengaruh terhadap usaha ternak ayam broiler di Kecamatan Sangatta Selatan. Berdasarkan hasil analisis lingkungan internal pada usaha ternak ayam broiler di Kecamatan Sangatta Selatan, diperoleh faktor-faktor beberapa kekuatan.

i. Tersedianya lahan yang dimiliki peternak untuk pembuatan kandang ayam yang digunakan untuk lokasi pembudidayaan ayam broiler sehingga menunjang keberhasilan usaha tersebut.

ii. Bahan baku seperti DOC (Day Old Chicken) dan pakan yang digunakan untuk menjalankan usaha ternak ayam broiler ini diperoleh langsung dari perusahaan mitra sehingga para peternak tidak perlu lagi merasa kesulitan dalam memenuhi bahan baku tersebut.

iii. Peralatan-peralatan yang diperlukan untuk melakukan budidaya ayam broiler juga disediakan oleh perusahaan mitra, sehingga para peternak hanya memenuhi kebutuan alatnya dengan cara membeli ke perusahaan mitra itu sendiri. 
iv. Perusahaan mitra bersedia memberikan pinjaman modal kepada peternak untuk kegiatan budidaya

v. Setelah melakukan budidaya ayam broiler, peternak tidak perlu lagi melakukan penjualan atau pemasaran terhadap hasil panennya. Karena pemasaran hasil panen ayam broiler dilakukan langsung oleh perusahaan. Perusahaan mitra tersebut telah memiliki tempat-tempat untuk melakukan penjualan, sehingga peternak tidak perlu merasa khawatir hasil panennya tidak akan laku di pasaran.

Selain dari faktor kekuatan di atas, ada pula faktor kelemahan pada usaha ternak ayam broiler di Kecamatan Sangatta Selatan, yang di antaranya adalah:

i. Alat-alat yang digunakan oleh para peternak ayam broiler di Kecamatan Sangatta Selatan masih tergolong sederhana, sehingga masih perlu dilakukan pengembangan lagi sehingga usaha ternak ini dapat lebih baik dengan teknologi yang lebih maju dan modern.

ii. Modal kerja yang dimiliki oleh peternak dengan pribadi masih terbatas, sehingga pengembangan alat dan bahan untuk kegiatan budidaya masih kurang dan hanya bergantung dengan bantuan dari perusahaan mitra.

iii. Para peternak ayam broiler di Kecamatan Sangatta Selatan kebanyakan melakukan budidaya ayam broiler dengan cara otodidak atau belajar sendiri tanpa ada pengalaman dan pelatihan-pelatihan sebelumnya.

iv. Ayam broiler adalah salah satu jenis unggas yang rentan terkena penyakit, namun yang dilakukan para peternak ayam broiler di Kecamatan Sangatta Selatan masih kurang maksimal dalam melakukan pengobatan sehingga para peternak belum mampu mengurangi tingkat kematian. Selama satu periode, tingkat kematian ayam sebesar $5 \%$ dari jumlah DOC yang masuk. Jumlah ayam yang mati sekitar \pm 300 ekor setiap periodenya.

Tabel 5. Matriks IFAS Usaha Ternak Ayam Broiler di Kecamatan Sangatta Selatan

\begin{tabular}{clccc}
\hline No & \multicolumn{1}{c}{ Faktor-Faktor Strategi Internal } & Bobot & Rating & Skor \\
\hline Kekuatan (Strengths) & 0,12 & 4 & 0,48 \\
1 & Tersedianya lahan & 0,12 & 4 & 0,48 \\
2 & Tersedianya bahan baku & 0,11 & 4 & 0,44 \\
3 & Tersedianya peralatan & 0,15 & 4 & 0,60 \\
4 & Tersedianya pinjaman modal dari perusahaan mitra & 0,16 & 4 & 0,64 \\
5 & Pemasaran hasil panen yang terjamin & 0,66 & & 2,64 \\
Jumlah Kekuatan & & & \\
Kelemahan (Weakness) & 0,09 & 3 & 0,27 \\
1 & Teknologi yang masih sederhana & 0,09 & 2 & 0,18 \\
2 & Terbatasnya modal kerja & 0,08 & 2 & 0,16 \\
3 & Kurangnya pengalaman mengenai budidaya ayam broiler & 0,08 & 2 & 0,16 \\
4 & Pengobatan kurang maksimal & 0,34 & & 0,77 \\
Jumlah Kelemahan & Total & 1 & 3,41 \\
\hline \multicolumn{2}{c}{}
\end{tabular}


Setelah melakukan analisis lingkungan internal yang mencakup kekuatan dan kelemahan, maka dilakukan analisis Matriks IFAS. Matriks IFAS dilakukan dengan pemberian bobot dan rating pada setiap faktor seperti disajikan Tabel 5.

Berdasarkan hasil analisis matriks IFAS total skor faktor internal yang diperoleh sebesar 3,41. Matrik IFAS menunjukkan bahwa faktor internal berupa kekuatan yang berperan dominan terhadap pengembangan usaha ternak ayam broiler di Kecamatan Sangatta Selatan adalah pemasaran hasil panen yang terjamin dengan skor 0,64 dan tersedianya bantuan modal dari perusahaan mitra dengan skor 0,60 .

\section{Analisis Lingkungan External}

Analisis lingkungan eksternal merupakan suatu analisis lingkungan yang mengidentifikasi peluang dan ancaman yang berpengaruh terhadap pengembangan usaha ternak ayam broiler di Kecamatan Sangatta Selatan. Analisis lingkungan eksternal tersebut dapat dilihat pada Tabel 6.

Tabel 6. Analisis Lingkungan Eksternal Usaha Ternak Ayam Broiler di Kecamatan Sangatta Selatan

\begin{tabular}{ll}
\hline \multicolumn{1}{c}{ Faktor-Faktor Eksternal } \\
\hline Peluang (Opportunities): & Ancaman (Threats): \\
\hline 1. Pertumbuhan rumah makan & 1. Letak peternak yang berdekatan \\
2. Tingginya populasi ayam broiler & 2. Wabah penyakit \\
3. Tingginya konsumsi daging ayam broiler & 3. Air sumur yang kotor dan zat asam masih \\
4. Limbah diolah menjadi pupuk kandang & tinggi \\
5. Ketersediaan tenaga kerja & 4. Banyaknya produk sejenis dari pesaing \\
\hline
\end{tabular}

Matriks EFAS merupakan hasil analisis lingkungan eksternal (peluang dan ancaman) usaha ternak ayam broiler di Kecamatan Sangatta Selatan dengan dilakukan pembobotan seperti disajikan pada Tabel 7.

Tabel 7. Matriks EFAS Usaha Ternak Ayam Broiler di Kecamatan Sangatta Selatan

\begin{tabular}{|c|c|c|c|c|}
\hline No & Faktor-Faktor Strategi Eksternal & Bobot & Rating & Skor \\
\hline & Peluang (Opportunities) & & & \\
\hline 1 & Pertumbuhan rumah makan & 0,10 & 3 & 0,30 \\
\hline 2 & Tingginya populasi ayam broiler & 0,14 & 4 & 0,56 \\
\hline 3 & Tingginya konsumsi daging ayam broiler & 0,16 & 4 & 0,64 \\
\hline 4 & Limbah diolah menjadi pupuk kandang & 0,10 & 3 & 0,30 \\
\hline \multirow[t]{2}{*}{5} & Ketersediaan tenaga kerja & 0,10 & 3 & 0,30 \\
\hline & $\begin{array}{l}\text { Jumlah Peluang } \\
\text { Ancaman (Threats) }\end{array}$ & 0,60 & & 2,10 \\
\hline 1 & Letak peternak yang berdekatan & 0,09 & 2 & 0,18 \\
\hline 2 & Wabah penyakit & 0,11 & 2 & 0,22 \\
\hline 3 & Air sumur yang kotor dan zat asam masih tinggi & 0,10 & 2 & 0,20 \\
\hline \multirow[t]{3}{*}{4} & Banyaknya produk sejenis dari pesaing & 0,10 & 2 & 0,20 \\
\hline & Jumlah Ancaman & 0,40 & & 0,80 \\
\hline & Total & 1 & & 2,90 \\
\hline
\end{tabular}

Berdasarkan hasil analisis Matriks EFAS menunjukkan bahwa faktor eksternal berupa peluang yang dominan adalah tingginya konsumsi daging ayam broiler dengan skor 0,64. Tingginya konsumsi daging ayam broiler masyarakat Kecamatan Sangatta Selatan menjadikan peluang dalam menjalankan usaha ternak ayam broiler di Kecamatan 
Sangatta Selatan, karena tingginya minat masyarakat terhadap daging ayam, sedangkan faktor eksternal berupa ancaman yang dominan adalah wabah penyakit dengan skor 0,22 .

\section{Matriks Internal-Eksternal}

Hasil yang diperoleh dari perhitungan Matriks IFAS dan EFAS akan digunakan untuk menyusun Matriks Internal-Eksternal (IE). Matriks IE digunakan dengan tujuan untuk memperoleh strategi bisnis yang lebih detail, sehingga dapat diketahui posisi usaha ternak ayam broiler di Kecamatan Sangatta Selatan. Matriks IE terbagi menjadi 9 sel, seperti yang disajikan pada Gambar 2.

Total Skor Faktor Strategi Internal

\begin{tabular}{|c|c|c|c|}
\hline & $\begin{array}{c}\text { Kuat } \\
(3,0-4,0)\end{array}$ & $\begin{array}{l}\text { Rata-Rata } \\
(2,0-2,99) \\
\end{array}$ & $\begin{array}{c}\text { Lemah } \\
(1,0-1,99)\end{array}$ \\
\hline 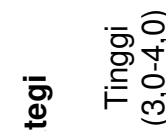 & $\stackrel{\text { I }}{\text { Grow and build }}$ & $\begin{array}{c}\text { II } \\
\text { Grow and build }\end{array}$ & $\begin{array}{c}\text { III } \\
\text { Hold and maintain }\end{array}$ \\
\hline 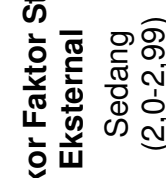 & $\begin{array}{c}\text { IV } \\
\text { Grow and build }\end{array}$ & $\begin{array}{c}\mathrm{V} \\
\text { Hold and maintain }\end{array}$ & $\begin{array}{c}\mathrm{VI} \\
\text { Harvest or divest }\end{array}$ \\
\hline 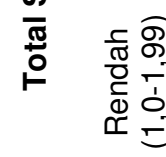 & $\begin{array}{c}\text { VII } \\
\text { Hold and maintain }\end{array}$ & $\begin{array}{c}\text { VIII } \\
\text { Harvest or divest }\end{array}$ & $\begin{array}{c}\text { IX } \\
\text { Harvest or divest }\end{array}$ \\
\hline
\end{tabular}

Total skor dalam matriks IFAS sebesar 3,41 dan total skor dalam matriks EFAS sebesar 2,90. Skor tersebut menempatkan usaha ternak ayam broiler di Kecamatan Sangatta Selatan pada sel IV yaitu Grow and build. Berdasarkan posisinya pada sel IV, maka strategi yang dapat dilakukan peternak adalah strategi intensif (memerlukan usahausaha yang intensif untuk meningkatkan posisi persaingan melalui produk yang ada), atau strategi integratif (perusahaan mengontrol atau memperoleh kendali atas distributor, pemasok, atau pesaing). Strategi yang paling tepat untuk usaha ternak ayam broiler di Kecamatan Sangatta Selatan saat ini adalah strategi intensif seperti meningkatkan posisi persaingan melalui produk yang ada.

\section{Analisis SWOT}

Analisis SWOT merupakan identifikasi berbagai faktor secara sistematis untuk merumuskan strategi dalam usaha ternak ayam broiler di Kecamatan Sangatta Selatan. Matriks SWOT merupakan alat yang digunakan untuk menyusun faktor-faktor strategis suatu perusahaan. Matriks SWOT dapat dilihat pada Tabel 8. 
Tabel 8. Matriks SWOT Usaha Ternak Ayam Broiler di Kecamatan Sangatta Selatan

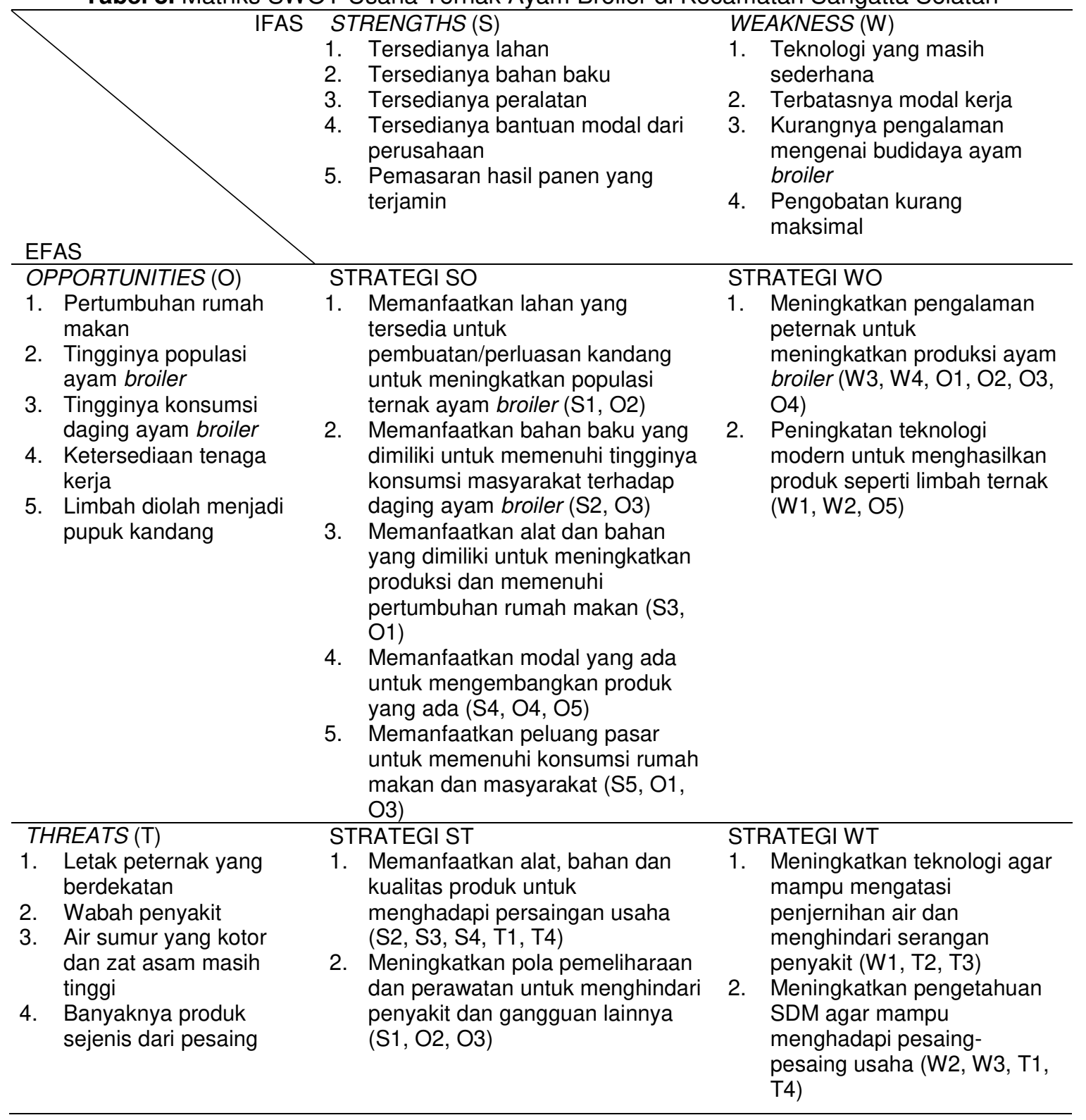

\section{Diagram SWOT}

Penentuan diagram SWOT terlebih dahulu dilakukan dengan menentukan koordinat $x$ dan koordinat $y$.

\section{Koordinat $\mathrm{x}$ :}

Penentuan koordinat $x$ ditentukan dari skor kekuatan dan kelemahan usaha ternak ayam broiler di Kecamatan Sangatta Selatan. Penentuan tersebut dapat dilihat pada rumus di bawah ini:

$$
\begin{gathered}
\text { Koordinat } x=\text { kekuatan }- \text { kelemahan } \\
\text { Koordinat } x=2,67-0,77 \\
\text { Koordinat } x=1,90
\end{gathered}
$$


2. Koordinat y:

Penentuan koordinat y ditentukan dari skor peluang dan ancaman yang berpengaruh terhadap usaha ternak ayam broiler di Kecamatan Sangatta Selatan. Penentuan tersebut dapat dilihat pada rumus di bawah ini:

$$
\begin{gathered}
\text { Koordinat } y=\text { peluang }- \text { ancaman } \\
\text { Koordinat } y=2,10-0,80 \\
\text { Koordinat } y=1,30
\end{gathered}
$$

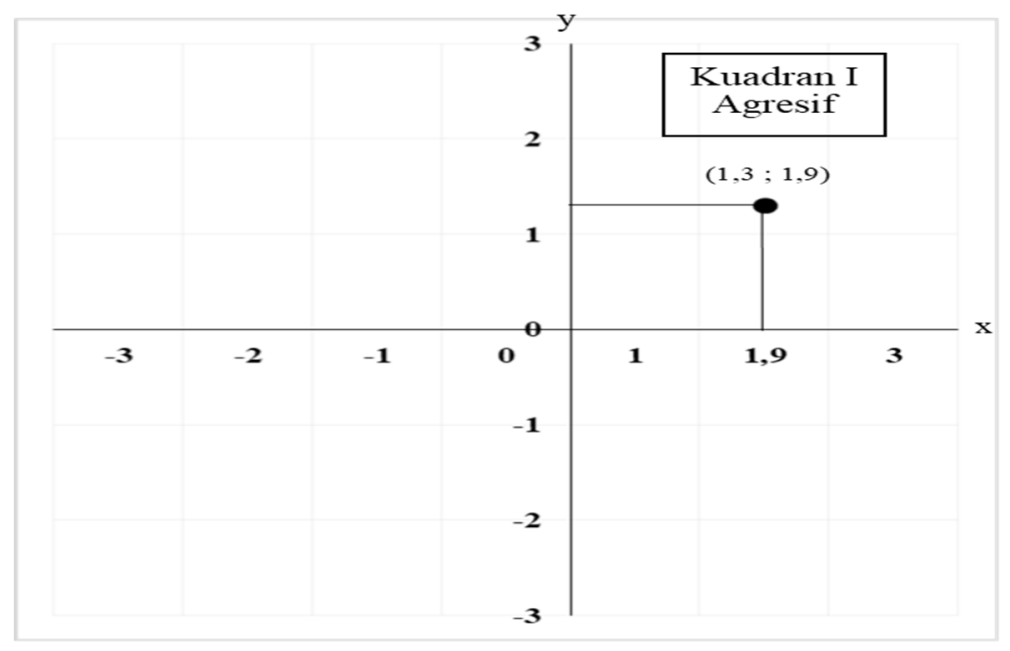

Gambar 3. Diagram SWOT Usaha Ternak Ayam Broiler Kecamatan Sangatta Selatan

Berdasarkan dari hasil tersebut dapat diketahui bahwa posisi usaha ternak ayam broiler berada pada kuadran I yang menandakan bahwa situasi ini sangat menguntungkan, usaha ini memiliki peluang dan kekuatan sehingga dapat memanfaatkan peluang yang ada. Kondisi demikian sesuai dengan penelitian terdahulu oleh Rusmiyati (2017), bahwa usaha ayam broiler di Kecamatan Teluk Pandan Kabupaten Kutai Timur berada pada kuadran I. Posisi ini menandakan bahwa usaha ternak ayam broiler di Kecamatan Sangatta Selatan merupakan usaha yang kuat dan berpeluang. Strategi yang harus diterapkan untuk usaha yang berada pada posisi ini adalah mendukung kebijakan pertumbuhan yang agresif, artinya usaha ternak ayam broiler berada dalam kondisi yang prima dan mantap sehingga sangat dimungkinkan untuk tumbuh dan meraih kemajuan secara maksimal. Posisi ini menunjukkan adanya peluang usaha, sehingga para peternak mampu mengambil kesempatan untuk mengembangkan usaha ternak ayam broiler di Kecamatan Sangatta Selatan.

\section{Kesimpulan}

Berdasarkan hasil penelitian ini, maka dapat disimpulkan bahwa usaha ternak ayam broiler di Kecamatan Sangatta Selatan berada pada kuadran I, yang berarti bahwa 
situasi ini sangat menguntungkan, usaha ini memiliki peluang dan kekuatan sehingga dapat memanfaatkan peluang yang ada. Strategi pengembangan pada usaha ternak ayam broiler di Kecamatan Sangatta Selatan adalah strategi agresif, yaitu menggunakan kekuatan untuk memanfaatkan peluang yang ada.

\section{Daftar Pustaka}

Afiyanti, Y. (2008). Focus Group Discussion (Diskusi Kelompok Terfokus) Sebagai Metode Pengumpulan Data Penelitian Kualitatif. Jurnal Keperawatan Indonesia. 12 (1) : 58-62.

Badan Perencanaan Pembangunan Daerah Provinsi Kalimantan Timur. (2017). Profil Daerah Provinsi Kalimantan Timur. Badan Perencanaan Pembangunan Daerah Provinsi Kalimantan Timur, Samarinda. http://bit.ly/2CfNebG. 19 Desember 2017.

Badan Pusat Statistik. (2014). Kutai Timur dalam Angka 2014. Katalog BPS: 1102001.6404. Badan Pusat Statistik Kabupaten Kutai Timur. Sangatta.

Badan Pusat Statistik. (2016). Kutai Timur dalam Angka 2016. Katalog BPS: 1102001.6404. Badan Pusat Statistik Kabupaten Kutai Timur. Sangatta.

Badan Pusat Statistik. (2017). Kabupaten Kutai Timur dalam Angka 2017. Katalog BPS: 1102001.6404. Badan Pusat Statistik Kabupaten Kutai Timur. Sangatta.

Badan Pusat Statistik. (2017). Kecamatan Sangatta Selatan dalam Angka 2017. Katalog BPS: 1102001.6404043. Badan Pusat Statistik Kabupaten Kutai Timur. Sangatta.

Kurniati, S.A. (2014). Peran Sektor Peternakan Ayam Pedaging dalam Perekonomian Kabupaten Kuantan Singingi Propins Riau. Jurnal Peternakan Indonesia. 16 (3) : 170-178.

Paramita, A. \& L. Kristiana. (2013). Teknik Focus Grup Discussion dalam Penelitian Kualitatif. Buletin Penelitian Sistem Kesehatan. 16 (2): 117-127.

Rangkuti, F. (2008). Analisis SWOT Teknik Membedah Kasus Bisnis. Gramedia Pustaka Utama. Jakarta.

Rusmiyati. (2017). Strategi Pengembangan Usaha Peternakan Ayam Ras Pedaging (Broiler) di Kecamatan Teluk Pandan Kabupaten Kutai Timur. Jurnal Pertanian Terpadu. 6 (1) : 59-73.

Sugiyono. (2014). Statistika Untuk Penelitian. Alfabeta, Bandung.

Ulup, N., I.R.H. Soesanto, \& S.K Inayah. (2015). Performa Ayam Broiler dengan Pemberian Serbuk Pinang sebagai Feed Aditive. Jurnal IImu Produksi dan Teknologi Hasil Peternakan. 3 (1) : 8-11.

Umam, M.K., H.S. Prayogi, \& V.M.A Nurgiatiningsih. (2015). Penampilan Produksi Ayam Pedaging Yang Dipelihara Pada Sistem Lantai Kandang Panggung dan Kandang Bertingkat. Jurnal-Jurnal Ilmu Peternakan. 24 (3) : 79-87. 